\title{
Cardiovascular Risk Prediction in Diabetes - Changes in the Prognostic Values of Modern Cardiovascular Biomarkers in Relation to Duration of Diabetes Mellitus
}

\section{Michael Resl}

Krankenhaus der Barmherzigen Bruder Wien https://orcid.org/0000-0002-1702-8945

\section{G Vila}

Medizinische Universitat Wien Universitatsbibliothek

M Heinzl

Krankenhaus der Barmherzigen Brüder Linz

\section{A Luger \\ Medizinische Universitat Wien}

\section{S Neuhold}

Sozialmedizinisches Zentrum Sud Kaiser-Franz-Josef-Spital

\section{R. Prager}

Krankenhaus Hietzing Wien

\section{R Wurm}

Medizinische Universitat Wien

M Hülsmann

Medizinische Universitat Wien

Martin Clodi ( $\square$ martin.clodi@bblinz.at)

Krankenhaus der Barmherzigen Brüder Linz

\section{Original investigation}

Keywords: Diabetes mellitus, Cardiovascular risk prediction, Biomarkers

Posted Date: August 4th, 2020

DOl: https://doi.org/10.21203/rs.3.rs-36833/v1

License: (1) This work is licensed under a Creative Commons Attribution 4.0 International License. Read Full License 


\section{Abstract}

Background: Based on the complex pathophysiology of type 2 diabetes and atherosclerosis we hypothesized a dynamic change in prognostic value of cardiovascular biomarkers over time.

Methods: In this prospective study 746 patients with type 2 diabetes mellitus, being followed up for 60 months were analysed. The primary endpoint was defined as unplanned hospitalization for cardiovascular disease or death. Beside others, especially the prognostic performance of the biomarkers of interest (GDF-15, NT-proBNP, hs-TnT) was evaluated in relation to quartiles of diabetesduration.

Results: In patients having a diabetes duration below 7 years InGDF-15 (HR 2.84; $p<0.01$ ) and Inhs-TnT (HR 2.96; $p<0.01)$ were significant predictors of the primary endpoint. LnAge (HR 40.11; $p<0.01)$ and InNT-proBNP (HR 1.61; $\mathrm{p}<0.01)$ were significant predictors in patients with a diabetes duration between 7 and 12 years. In the third quartile (diabetes duration 12-22 years) InAge (HR 13.09; $p=0.041$ ), urinary albumin to creatinine ratio (HR 2.74; $p=0.001)$ and InNT-proBNP (HR 1.81, $p<0.001)$ predicted the endpoint. In patients with a diabetes duration above 22 years, InAge (HR 50.79; $p=0.002$ ) and InNTproBNP $(H R 2.1 ; p<0.01)$ were the only significant predictors of the endpoint.

Conclusion: Prognostic power of cardiovascular biomarkers changes dynamically in relation to duration of type 2 diabetes mellitus. In patients with shorter duration of the disease markers of subclinical cardiovascular dysfunction and inflammation perform better than markers of systemic advanced organ dysfunction and cardiovascular disease.

\section{Background}

Cardiovascular disease remains a leading cause of mortality in patients with diabetes mellitus ${ }^{1}$.

Results of major cardiovascular outcome studies have impressively demonstrated that comprehensive inclusion criteria selecting special patient cohorts are the corner stone for demonstrating substance specific cardiovascular effects ${ }^{2-4}$.

In these studies patient selection was exclusively based on demographic criteria and classical cardiovascular risk factors with level of evidence $\mathrm{C}$, consequently resulting in a relatively imprecise estimation of true absolute cardiovascular risk.

Cardiac blood biomarkers, especially N-terminal-pro-B-type natriuretic peptide (NT-proBNP) has come to our attention in this setting ${ }^{5-7}$. Beside registries also in large randomized trials NT-proBNP is already tested in regard of risk estimation and treatment response (SAVOR-TIMI, EXAMINE). Despite promising results only few guidelines recommend using NT-proBNP in this setting ${ }^{8}$. Combining prognostic information of different biomarkers is superior to classical cardiovascular risk calculators in a primary as well as in a secondary prevention setting ${ }^{9}$. 
Beside NT-proBNP, high-sensitive troponin-t (hs-TnT) and Growth differentiation factor 15 (GDF-15) seem to be the most promising ones for additive value. Reflecting different pathophysiological pathways of atherosclerosis these markers provide an independent additional prognostic value with considerable net reclassification indices ${ }^{10,11}$.

The heterogenity combined with the complex pathophysiology of diabetes and heart disease might also affect the predictive value of cardiovascular biomarkers interacting with other clinical cofactors 12,13 .

Results of almost every major biomarker study are based on a single measurement of the markers of interest. However several studies have shown that there is a dynamic change of different biomarkers even during short follow up which might tremendously affect the predictive power of the biomarkers over time ${ }^{14,15}$. Moreover, it is hypothesized, that cardiovascular events are a function of diabetes duration, which also might be reflected in the predictive power of biomarkers.

We hypothesized that there is a dynamic change in the predictive value of biomarkers as well as classical cardiovascular risk factors over time. In this study we aimed to evaluate the changing prognostic impact of the most important cardiovascular biomarkers and risk factors in relation to diabetes duration.

\section{Methods}

\section{Design}

Patients with diabetes mellitus type 2 attending the diabetes outpatient clinics of Vienna's General Hospital and Hietzing Hospital Vienna were consecutively included. All data and blood samples were obtained at this visit. Adhering to the guidelines of American Diabetes Association the diagnosis of diabetes was based on fasting glucose or a pathological oral glucose tolerance test. This prospective observational study was approved by the Ethics committees of the Medical University of Vienna and Hietzing Hospital Vienna and guided according to the declaration of Helsinki and its amendments. All patients gave written informed consent. Since this study was designed as an observational registry unwillingness to participate was the only exclusion criterion. At inclusion, beside lab samples a complete medical history including the duration of diabetes, presence of any cardiovascular and other diseases was recorded. An electrocardiogram was performed and analysed for abnormalities.

\section{Analytical Methods}

At index time blood was drawn from an antecubital vein. Parameters including lipid values, liver enzymes, creatinine, blood urea nitrogen, $\mathrm{HbA} 1 \mathrm{c}$ and plasma glucose were analysed in a certified laboratory. NTproBNP was measured using the Cobas $\mathrm{H} 232$ system, with intra - and interessay $\mathrm{CVs}$ of $<15 \%$ at $60-1200 \mathrm{pg} / \mathrm{mL}$ and $<20 \%$ at $1200-9000 \mathrm{pg} / \mathrm{mL}$.

hs-TnT was measured with the Elecsys Assay by Roche Diagnostics (Rotkreuz, Switzerland). As described by the manufacturer in the assay kit (Roche Diagnostics), the inter-assay CV (coefficient of variation) was 
$8 \%$ at $10 \mathrm{ng} / \mathrm{l}$ and $2.5 \%$ at $100 \mathrm{ng} / \mathrm{l}$. The intra-assay $\mathrm{CV}$ was $5 \%$ at $10 \mathrm{ng} / \mathrm{l}$ and $1 \%$ at $100 \mathrm{ng} / \mathrm{l}$.

GDF-15 was measured using a sandwich ELISA kit (Roche Diagnostics Rotkreuz Switzerland) with intraand interassay CVs of $4.9 \%$ at $445 \mathrm{ng} / \mathrm{l}, 3.8 \%$ at $1664 \mathrm{ng} / \mathrm{l}$ and $3.3 \%$ at $4880 \mathrm{ng} / \mathrm{l}$. All biomarkers were analyzed in the same laboratory. GDF-15 and hs-TnT were measured collectively with the same kit, whereas NT-proBNP was measured by the POC-System at index time.

\section{Endpoint}

The primary endpoint was defined as a composite endpoint of unplanned hospitalization for cardiovascular causes or all cause mortality. Unplanned hospitalization for cardiovascular causes was defined as an admission based on acute coronary syndrome -myocardial infarction, decompensation based on heart failure, clinical worsening based on arrhythmia (atrial fibrillation, higher degree bundle branch block or ventricular tachycardia), stroke/TIA, critical leg perfusion based on peripheral arterial occlusive disease or venous thrombosis. Unplanned hospitalization for cardiovascular causes and allcause mortality were also analysed separately in a second step as two different secondary endpoints. Hospitalization and mortality data were obtained from the regional hospital data network. Information about hospitalization for cardiac events was obtained from hospital files by a cardiologist who was unaware of the results. Median follow up was 60.0 (IQR 60.0-60.0) months.

\section{Statistical Analysis}

Continuous variables are expressed as means + standard deviation, skewedly distributed variables are presented as medians (interquartile range); categorical variables are presented as frequencies and percentages. Sample size calculation was based on an expected log hazard ratio of 0.5 and an expected event rate of $10 \%$. For alpha 0.05 and power 0.9 sample size of 600 patients was obtained. To analyse the predictive value of the biomarkers (NT-proBNP, GDF-15 and Troponin T) in relation to the duration of diabetes mellitus, the collective was split according to quartiles of diabetes duration (Quartile 1: $<7$ years, Quartile 2: 7-12 years, Quartile 3: 12-22 years and Quartile 4: > 22 years). Cox regression analysis using a stepwise forward approach including the variables Inage, IneGFR, InLDL - cholesterol, urinary albumin to creatinine ratio, InNT-proBNP, InGDF-15 and InhsTroponin-t were run for the primary endpoint (Unplanned hospitalization for cardiovascular causes and all-cause mortality) and the secondary endpoints (Unplanned hospitalization for cardiovascular causes, all-cause mortality).

\section{Results}

The final analysis was performed in 746 patients ( 420 male $56.3 \%$ and 326 female $43.7 \%$ ). Ischemic heart disease has previously been diagnosed in 84 patients (11.2\%). Median eGFR was 72.7 (61.5-85.3) $\mathrm{ml} / \mathrm{min} / 1.73 \mathrm{~m}^{2}$ and median urinary albumin to creatinine ratio was $6.7 \mathrm{mg} / \mathrm{g}(3.1-22.2)$. Hypertension was prevalent in 508 (68\%) patients. In total 408 (54.7\%) patients were treated with either an ACEinhibitor or an Angiotensin Receptor Blocker. A total of 203 patients (27.2\%) had a beta-blocker included in their therapeutic regimen. Diuretics were prescribed in $230(30.8 \%)$ patients, while treatment with a 
calcium channel blocker was documented in 111 (14.9\%) patients. Statins were used in 317 (42.5\%) patients.

339 (45.4\%) patients were on metformin therapy, 196 (26.3\%) patients had a sulfonylurea included in their glucose lowering therapy and 508 (68\%) patients were treated with insulin. In total 408 (54.7\%) patients had a combination of insulin therapy and an oral glucose lowering agent. Pioglitazone was prescribed in $25(3.4 \%)$ patients. Demographic data according to the quartiles of diabetes duration are presented in Table 1.

Table 1

Demographic parameters in relation to diabetes duration

\begin{tabular}{|c|c|c|c|c|}
\hline \multirow[t]{2}{*}{ Variable } & $\begin{array}{l}\text { Diabetes } \\
\text { duration }\end{array}$ & $\begin{array}{l}\text { Diabetes } \\
\text { duration }\end{array}$ & $\begin{array}{l}\text { Diabetes } \\
\text { duration }\end{array}$ & $\begin{array}{l}\text { Diabetes } \\
\text { duration }\end{array}$ \\
\hline & $<7$ years & $7-12$ years & $12-22$ years & $>22$ years \\
\hline Age (years) & $57 \pm 13^{\star}$ & $60 \pm 13^{*}$ & $63 \pm 13^{*}$ & $62 \pm 13^{\star}$ \\
\hline eGFR (MDRD) & $78.16 \pm 18.00 *$ & $72.58 \pm 18.78^{\star}$ & $69.45 \pm 17.01^{*}$ & $71.75 \pm 17.6^{*}$ \\
\hline LDL (mg/dl) & $110 \pm 30 *$ & $103 \pm 27 *$ & $103 \pm 26^{*}$ & $103 \pm 28 *$ \\
\hline HbA1c (\%) & $6.8 \pm 1.3^{\star}$ & $7.2 \pm 1.2^{\star}$ & $7.4 \pm 1.2^{\star}$ & $7.4 \pm 1.1^{\star}$ \\
\hline $\begin{array}{l}\text { Albumin/Creat Ratio } \\
\mathrm{mg} / \mathrm{g}\end{array}$ & $63 \pm 276$ & $99 \pm 431$ & $108 \pm 383$ & $83 \pm 316$ \\
\hline Systolic Blood Pressure & $144 \pm 24$ & $144 \pm 21$ & $147 \pm 25$ & $142 \pm 24$ \\
\hline Diast.Blood Pressure & $83 \pm 12^{*}$ & $81 \pm 10^{\star}$ & $80 \pm 11 *$ & $78 \pm 12^{\star}$ \\
\hline NT-proBNP (pg/ml) & $150 \pm 260 *$ & $182 \pm 354^{*}$ & $246 \pm 453^{\star}$ & $193 \pm 367^{\star}$ \\
\hline hsTnT (pg/ml) & $10 \pm 10 *$ & $11 \pm 10$ & $12 \pm 9 *$ & $10 \pm 10 *$ \\
\hline GDF-15 (ng/L) & $1834 \pm 2097$ & $1785 \pm 1261$ & $1893 \pm 1198$ & $1465 \pm 983$ \\
\hline
\end{tabular}

\section{Event rates}

During a median follow up of 60 months 171 patients (22.9\%) reached the primary endpoint (composite of unplanned hospitalitation for cardiovascular causes or all cause mortality) Among the quartiles of diabetes duration there was no significant difference in event rates. Results of all endpoints (primary endpoint and secondary endpoints) are shown in in Table 2. 
Table 2

Event Rates, Primary Endpoint, Secondary Endpoints

\begin{tabular}{|c|c|c|c|c|}
\hline & $\begin{array}{l}\text { Quartile } 1 \\
(n=200)\end{array}$ & $\begin{array}{l}\text { Quartile } 2 \\
(n=190)\end{array}$ & $\begin{array}{l}\text { Quartile } 3 \\
(n=176)\end{array}$ & $\begin{array}{l}\text { Quartile } \\
4 \\
(n= \\
180)\end{array}$ \\
\hline Duration of Diabetes (years) & $<7$ years & $7-12$ years & $\begin{array}{l}12- \\
22 \text { years }\end{array}$ & 22 years \\
\hline $\begin{array}{l}\text { Primary Endpoint: } \\
\text { Hospitalization for cardiovascular cause } \\
\text { or all-cause mortality }\end{array}$ & $43(21.5 \%)$ & $44(23.2 \%)$ & $45(25.6 \%)$ & $\begin{array}{l}39 \\
(21.7 \%)\end{array}$ \\
\hline $\begin{array}{l}\text { Secondary Endpoint: } \\
\text { Hospitalization for cardiovascular causes }\end{array}$ & $31(15.5 \%)$ & $29(15.3 \%)$ & $36(20.5 \%)$ & $\begin{array}{l}29 \\
(16.1 \%)\end{array}$ \\
\hline $\begin{array}{l}\text { Secondary Endpoint: } \\
\text { All cause mortality }\end{array}$ & $17(8.5 \%)$ & $18(9.5 \%)$ & $16(9.1 \%)$ & $\begin{array}{l}18 \\
(10.0 \%)\end{array}$ \\
\hline
\end{tabular}

\section{Predictive value of biomarkers according to duration of diabetes}

In univariate Cox regression models InNT-proBNP, Inhs-TnT, and InGDF-15 were significant predictors of the primary endpoint in relation to quartiles of diabetes duration (Table 3).

Table 3

Final models of the stepwise Cox regression models of the total population

\begin{tabular}{|llll|}
\hline Variable & Hazard Ratio & Cl & p-Value \\
\hline Total Cohort & & & \\
\hline InNT-proBNP & 1.53 & $1.30-1.80$ & $\mathrm{p}<0.01$ \\
\hline InGDF-15 & 1,54 & $1.13-2.09$ & $\mathrm{p}=0.006$ \\
\hline Inhs-Tnt & 3.81 & $2.08-6.99$ & $\mathrm{p}<0.01$ \\
\hline Inage & 38.86 & $2.01-518.41$ & $\mathrm{p}=0.006$ \\
\hline
\end{tabular}

The predictive power of the different cardiovascular biomarkers changes in relation to diabetes duration for the primary endpoint and for the prespecified secondary endpoints (unplanned hospitalization for cardiovascular causes, all-cause mortality) (Table 4). 
Table 4

Predictors of the primary endpoint (composite endpoint of unplanned hospitalization for cardiovascular causes and all cause mortality) and the secondary endpoints

\begin{tabular}{|c|c|c|c|c|}
\hline \multirow[t]{3}{*}{ Endpoint } & $\begin{array}{l}\text { Diabetes } \\
\text { Duration } \\
\text { Quartile } 1\end{array}$ & $\begin{array}{l}\text { Diabetes } \\
\text { Duration } \\
\text { Quartile } 2\end{array}$ & $\begin{array}{l}\text { Diabetes } \\
\text { Duration } \\
\text { Quartile } 3\end{array}$ & $\begin{array}{l}\text { Diabetes } \\
\text { Duration } \\
\text { Quartile } 4\end{array}$ \\
\hline & $<7$ years & $7-12$ years & $12-22$ years & $>22$ years \\
\hline & $(n=200)$ & $(n=190)$ & $(n=176)$ & $(n=180)$ \\
\hline \multirow{6}{*}{$\begin{array}{l}\text { Primary Endpoint unplanned } \\
\text { hospitalization for cardiovascular } \\
\text { causes and all cause mortality }\end{array}$} & InGDF-15 & InAge & InAge & InAge \\
\hline & $\begin{array}{l}\text { (HR 2.84; } \\
\text { Cl 1.8-4.5; } \\
\mathrm{p}=0.001\end{array}$ & $\begin{array}{l}(\mathrm{HR} 40.11 ; \mathrm{Cl} \\
4.5-355.7 ; \mathrm{p} \\
=0.01)\end{array}$ & $\begin{array}{l}(\mathrm{HR} 13.09 ; \mathrm{Cl} \\
1.12-155.43 ; \mathrm{p} \\
=0.041)\end{array}$ & $\begin{array}{l}(\mathrm{HR} 50.79 ; \mathrm{Cl} \\
4.34-593.87 \\
\mathrm{p}=0.002)\end{array}$ \\
\hline & Inhs-TnT & InNT-proBNP & InNT-proBNP & InNT-proBNP \\
\hline & $\begin{array}{l}(2.96 ; \mathrm{Cl} \\
2.1-4.3 ; \mathrm{p} \\
=0.001)\end{array}$ & $\begin{array}{l}(\mathrm{HR} 1.61 ; \mathrm{Cl} \\
1.22-2.14 ; \mathrm{p} \\
=0.01)\end{array}$ & $\begin{array}{l}(\mathrm{HR} 1.81 ; \mathrm{Cl} \\
1.37-2.40 ; \mathrm{p}= \\
0.001)\end{array}$ & $\begin{array}{l}\text { (HR 2.10; Cl } \\
1.56-2.83 ; \mathrm{p} \\
=0.001)\end{array}$ \\
\hline & & & $U A C R$ & \\
\hline & & & $\begin{array}{l}(\mathrm{HR} 2.74 ; \mathrm{Cl} \\
1.51-4.97 ; \mathrm{p}= \\
0.001)\end{array}$ & \\
\hline \multirow{4}{*}{$\begin{array}{l}\text { Secondary Endpoint unplanned } \\
\text { hospitalization for cardiovascular } \\
\text { causes }\end{array}$} & $\begin{array}{l}\text { InNT- } \\
\text { proBNP }\end{array}$ & InNT-proBNP & InNT-proBNP & InNT-proBNP \\
\hline & $\begin{array}{l}\text { (HR 2.00; } \\
\text { Cl 1.29- } \\
3.12 ; p= \\
0.002)\end{array}$ & $\begin{array}{l}(\mathrm{HR} 1.78 ; \mathrm{Cl} \\
1.30-2.50 ; \mathrm{p} \\
=0.001)\end{array}$ & $\begin{array}{l}(\mathrm{HR} 2.05 ; \mathrm{Cl} \\
1.54-2.71 ; \mathrm{p}= \\
0.001)\end{array}$ & $\begin{array}{l}\text { (HR 2.10; Cl } \\
1.49-2.98 ; \mathrm{p} \\
=0.001)\end{array}$ \\
\hline & Inhs-TnT & InAge & $U A C R$ & InAge \\
\hline & $\begin{array}{l}\text { (HR 2.47; } \\
\text { Cl 1.55- } \\
3.93 ; p= \\
0.001)\end{array}$ & $\begin{array}{l}(\mathrm{HR} 17.52 ; \mathrm{Cl} \\
1.40- \\
218.92 ; p= \\
0.026)\end{array}$ & $\begin{array}{l}\text { (HR 3.28; Cl } \\
1.67-6.47 ; p= \\
0.001)\end{array}$ & $\begin{array}{l}(\mathrm{HR} 85.67 ; \mathrm{Cl} \\
4.46- \\
1643.87 ; p= \\
0.001)\end{array}$ \\
\hline \multirow{2}{*}{$\begin{array}{l}\text { Secondary Endpoint } \\
\text { all cause mortality }\end{array}$} & $\ln G D F-15$ & $\ln G D F-15$ & InNT-proBNP & InNT-proBNP \\
\hline & $\begin{array}{l}\text { (HR 5.12; } \\
\text { Cl 2.64- } \\
9.90 ; p= \\
0.001)\end{array}$ & $\begin{array}{l}\text { (HR 2.88; Cl } \\
1.23-6.76 ; \mathrm{p} \\
=0.015)\end{array}$ & $\begin{array}{l}(\mathrm{HR} 2.16 ; \mathrm{Cl} \\
1.36-3.44 ; \mathrm{p}= \\
0.001)\end{array}$ & $\begin{array}{l}(\mathrm{HR} 2.01 ; \mathrm{Cl} \\
1.26-3.20 ; \mathrm{p} \\
=0.003)\end{array}$ \\
\hline
\end{tabular}

* all models adjusted for Inage, IneGFR, InLDL - cholesterol, urinary albumin to creatinine ratio, InNTproBNP, InGDF-15 and Inhs-Troponin-T 


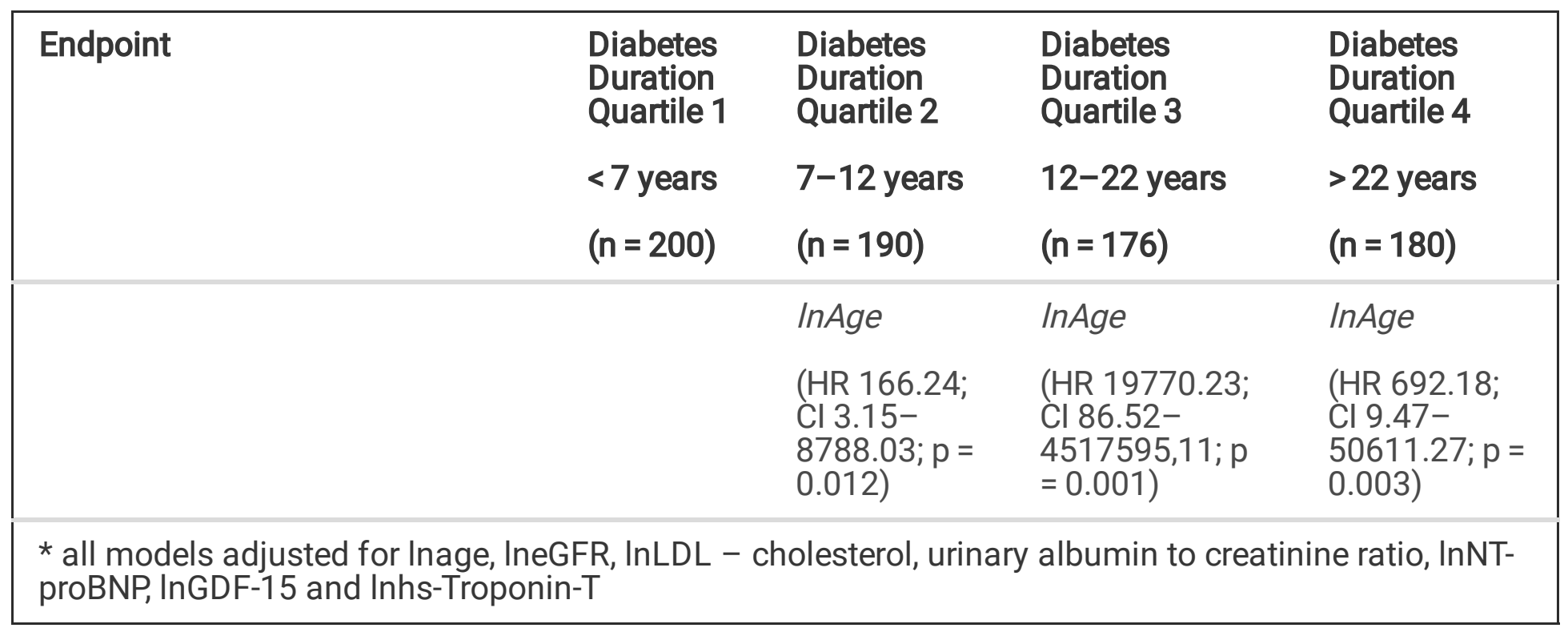

\section{Discussion}

Our first unexpected result revealed that neither hospitalization for cardiovascular causes nor all cause mortality are a function of diabetes duration.

Despite this unexpected finding the prognostic value of cardiovascular biomarkers changes dynamically in relation to duration of type 2 diabetes mellitus, which implies that pathophysiology of cardiovascular events changes over time.

In patients with a diabetes duration below 7 years GDF-15 and hs-TnT are the best predictors of the composite endpoint of unplanned hospitalization for cardiovascular causes and all cause mortality.

In patients with longstanding type 2 diabetes (diabetes duration $>7$ years) age and NT-proBNP are throughout the best predictors of the composite endpoint, whereas GDF-15 and hs-TnT have lost their prognostic value.

Unplanned hospitalization for cardiovascular causes and all-cause mortality were also analysed separately as two different secondary endpoints, providing additional interesting information. Regarding unplanned hospitalization for cardiovascular causes NT-proBNP was the only neurohumoral biomarker being predictive in all classes of diabetes duration. This extreme stability confirms the clinical value of this parameter.

Considering all cause mortality GDF-15 remained a stable marker for the earlier phase of diabetes until NT-proBNP gets superiority to predict mortality after 12 years of diabetes duration.

From a pathophysiological point of view NT-proBNP reflects volume and pressure overload in a failing heart. All stages from subclinical cardiovascular dysfunction to advanced stages of heart disease and heart failure can be detected with increasing blood levels depending of the severity of alterations.

Tremendous increases can be seen in situations with acute volume or pressure overload of the ventricles. 
This mainly occurs when cardiac function worsens acutely and might explain the predictive power to detect cardiac hospitalizations better than other neurohormones. Moreover BNP and NT-proBNP are also induced by inflammation and interact directly with glucose metabolism ${ }^{16}$. Many data suggest that NTproBNP is a mediator of gluco-inflammatory myocardial crosstalk in diabetes, which also explains the high and independent predictive power of this peptide ${ }^{17}$.

GDF-15 is a cytokine expressed in adipocytes physiologically decreasing food intake, body weight and adiposity. There is a clear correlation of GDF-15 with body mass index, body fat, glucose and C-reactive protein making it an attractive biomarker in diabetes. From a cardiovascular point of view, GFD-15 works as a stress responsive cytokine expressed also in cardiomyocytes and vascular smooth muscle cells. Unlike NT-proBNP, GDF-15 is primarily a marker of inflammation fibrosis, cell injury and atherosclerosis ${ }^{18}$, 19. These malignant three are the main trigger of progression of cardiac disease. Thus high GDF-15 might reflect the activity of cardiac processes leading to myocardial or coronary dysfunction. Elevated levels of GDF-15 can already be seen in early hypertension, when hypertrophy occurs ${ }^{20}$ but also fuels atherosclerosis by inflammatory processes ${ }^{21,22}$ whereas NT-proBNP reflects the severity. Heart failure with preserved ejection fraction (HFpEF) which is mainly based on fibrosis is a common cardiac disease in patients with diabetes. Even here GDF-15 appears to be a significant biomarker of the disease ${ }^{23}$.

It can be speculated that the complementary effect of GDF-15 in early diabetes and the prognostic effect of NT-proNBP regarding mortality is based on different immanent information. GDF-15 might be a better marker of disease activity during development of cardiac disease (during the first years of diabetes onset), whereas NT-proBNP is more a marker of disease severity being a better predictor in later stages of full blown cardiac disease. This would be in accordance with a strong trend to a decrease of GDF-15 in longstanding diabetes but an increase in NT-proBNP over time.

Beside this two most prominent markers also UACR has some independent information as already known from earlier publications ${ }^{24}$.

UACR is a marker for atherosclerosis and diabetic nephropathy ${ }^{25}$. As shown urinary albumin to creatinine ratio performs pretty well in patients with longstanding diabetes while there is no predictive information in patients having a diabetes duration below 12 years. This is well in line with studies showing that about $40 \%$ of patients with "diabetic" nephropathy have no albumin excretion, especially at the onset of the disease ${ }^{26}$. In accordance UACR has a a poor performance at the beginning of the disease with probable early onset of kidney disease.

In a data driven cluster analysis Ahlqvist and colleagues have defined 5 different subgroups of diabetes mellitus. Moreover they impressively demonstrated differences in risk of diabetic complications in relation to the dominating pathophysiologic factor. These findings are well in line with our results also showing that cardiovascular event rates are not directly related to duration of diabetes mellitus, but might be based on different phenotypes. Based on this heterogenity in phenotypes of diabetes our data add some further information as there is an additional heterogeneity over time in the biomarker profile. We 
have to confess, that in this work only few, although important-markers were tested and larger datasets will give a clearer picture in the future.

\section{Conclusions}

Taken together our data speak for a dynamic change of the prognostic information of cardiovascular biomarkers over time and show that cardiovascular events are not related to the duration of diabetes mellitus. Quite different biomarkers characterize different time phases of diabetes duration and are directly related to outcome. In how far these phases are temporal transitions accompanied by neurohumoral/pathophysiologic transitions or demonstrate different phenotypes of diabetes and cardiovascular disease like Ahlquivst tried to demonstrate cannot be proven by our data but would be an important feature for the future.

\section{Abbreviations}

- N-terminal-pro-B-type natriuretic peptide (NT-proBNP)

- high-sensitive troponin-t (hs-TnT)

- Growth differentiation factor 15 (GDF-15)

\section{Declarations}

\section{Ethics approval and consent to participate}

This prospective observational study was approved by the Ethics committees of the Medical University of Vienna and Hietzing Hospital Vienna and guided according to the declaration of Helsinki and its amendments. All patients gave written informed consent. Since this study was designed as an observational registry unwillingness to participate was the only exclusion criterion.

\section{Consent for publication}

Not applicable

\section{Availability of data and materials}

The datasets used and/or analysed during the current study are available from the corresponding author on reasonable request.

\section{Competing interests}


The authors declare that they have no competing interests.

\section{Funding}

The whole study was completely funded by the Medical university of Vienna

\section{Authors' contributions}

M.Resl researched and analysed data and wrote the initial draft of the manuscript; G.Vila researched data and corrected the manuscript; $\mathrm{M}$. Heinzl participated in data analysis and the writing process; A. Luger analysed data and edited the manuscript, S. Neuhold analysed data and edited the manuscript, R.Prager analysed data and edited the manuscript, R.Wurm analysed data and edited the manuscript, M. Hülsmann designed the study, researched and analysed data and participated in writing and correcting the manuscript, M. Clodi designed the study, researched and analysed data and participated in writing and correcting the manuscript.

\section{Acknowledgements}

We want to thank Isabella Brodnjak for assistance with data collection

\section{References}

1. Cheng YJ, Imperatore G, Geiss LS, Saydah SH, Albright AL, Ali MK, Gregg EW. Trends and Disparities in Cardiovascular Mortality Among U.S. Adults With and Without Self-Reported Diabetes, 1988-2015. Diabetes Care 2018;41(11):2306-2315.

2. Neal B, Perkovic V, Matthews DR. Canagliflozin and Cardiovascular and Renal Events in Type 2 Diabetes. N Engl J Med 2017;377(21):2099.

3. Wiviott SD, Raz I, Bonaca MP, Mosenzon O, Kato ET, Cahn A, Silverman MG, Zelniker TA, Kuder JF, Murphy SA, Bhatt DL, Leiter LA, McGuire DK, Wilding JPH, Ruff CT, Gause-Nilsson IAM, Fredriksson M, Johansson PA, Langkilde AM, Sabatine MS, Investigators D-T. Dapagliflozin and Cardiovascular Outcomes in Type 2 Diabetes. N Engl J Med 2018.

4. Zinman B, Wanner C, Lachin JM, Fitchett D, Bluhmki E, Hantel S, Mattheus M, Devins T, Johansen OE, Woerle HJ, Broedl UC, Inzucchi SE, Investigators E-RO. Empagliflozin, Cardiovascular Outcomes, and Mortality in Type 2 Diabetes. N Engl J Med 2015;373(22):2117-28.

5. Bidadkosh A, Lambooy SPH, Heerspink HJ, Pena MJ, Henning RH, Buikema H, Deelman LE. Predictive Properties of Biomarkers GDF-15, NTproBNP, and hs-TnT for Morbidity and Mortality in Patients With Type 2 Diabetes With Nephropathy. Diabetes Care 2017;40(6):784-792. 
6. Epshteyn V, Morrison K, Krishnaswamy P, Kazanegra R, Clopton P, Mudaliar S, Edelman S, Henry R, Maisel A. Utility of B-type natriuretic peptide (BNP) as a screen for left ventricular dysfunction in patients with diabetes. Diabetes Care 2003;26(7):2081-7.

7. Gori M, Gupta DK, Claggett B, Selvin E, Folsom AR, Matsushita K, Bello NA, Cheng S, Shah A, Skali H, Vardeny O, Ni H, Ballantyne CM, Astor BC, Klein BE, Aguilar D, Solomon SD. Natriuretic Peptide and High-Sensitivity Troponin for Cardiovascular Risk Prediction in Diabetes: The Atherosclerosis Risk in Communities (ARIC) Study. Diabetes Care 2016;39(5):677-85.

8. Authors/Task Force M, Ryden L, Grant PJ, Anker SD, Berne C, Cosentino F, Danchin N, Deaton C, Escaned J, Hammes HP, Huikuri H, Marre M, Marx N, Mellbin L, Ostergren J, Patrono C, Seferovic P, Uva MS, Taskinen MR, Tendera M, Tuomilehto J, Valensi P, Zamorano JL, Guidelines ESCCfP, Zamorano JL, Achenbach S, Baumgartner H, Bax JJ, Bueno H, Dean V, Deaton C, Erol C, Fagard R, Ferrari R, Hasdai D, Hoes AW, Kirchhof P, Knuuti J, Kolh P, Lancellotti P, Linhart A, Nihoyannopoulos P, Piepoli MF, Ponikowski P, Sirnes PA, Tamargo JL, Tendera M, Torbicki A, Wijns W, Windecker S, Document R, De Backer G, Sirnes PA, Ezquerra EA, Avogaro A, Badimon L, Baranova E, Baumgartner H, Betteridge J, Ceriello A, Fagard R, Funck-Brentano C, Gulba DC, Hasdai D, Hoes AW, Kjekshus JK, Knuuti J, Kolh P, Lev E, Mueller C, Neyses L, Nilsson PM, Perk J, Ponikowski P, Reiner Z, Sattar N, Schachinger V, Scheen A, Schirmer H, Stromberg A, Sudzhaeva S, Tamargo JL, Viigimaa M, Vlachopoulos C, Xuereb RG. ESC Guidelines on diabetes, pre-diabetes, and cardiovascular diseases developed in collaboration with the EASD: the Task Force on diabetes, pre-diabetes, and cardiovascular diseases of the European Society of Cardiology (ESC) and developed in collaboration with the European Association for the Study of Diabetes (EASD). Eur Heart J 2013;34(39):3035-87.

9. Goliasch G, Silbernagel G, Kleber ME, Grammer TB, Pilz S, Tomaschitz A, Bartko PE, Maurer G, Koenig W, Niessner A, Marz W. Refining Long-Term Prediction of Cardiovascular Risk in Diabetes - The VILDIA Score. Sci Rep 2017;7(1):4700.

10. Gerstein HC, Pare G, McQueen MJ, Lee SF, Hess S, Investigators OT. Validation of the ORIGIN Cardiovascular Biomarker Panel and the Value of Adding Troponin I in Dysglycemic People. J Clin Endocrinol Metab 2017;102(7):2251-2257.

11. Resl M, Clodi M, Vila G, Luger A, Neuhold S, Wurm R, Adlbrecht C, Strunk G, Fritzer-Szekeres M, Prager R, Pacher R, Hulsmann M. Targeted multiple biomarker approach in predicting cardiovascular events in patients with diabetes. Heart 2016;102(24):1963-1968.

12. Ahlqvist E, Storm P, Karajamaki A, Martinell M, Dorkhan M, Carlsson A, Vikman P, Prasad RB, Aly DM, Almgren P, Wessman Y, Shaat N, Spegel P, Mulder H, Lindholm E, Melander O, Hansson O, Malmqvist U, Lernmark A, Lahti K, Forsen T, Tuomi T, Rosengren AH, Groop L. Novel subgroups of adult-onset diabetes and their association with outcomes: a data-driven cluster analysis of six variables. Lancet Diabetes Endocrinol 2018;6(5):361-369.

13. Defronzo RA. Banting Lecture. From the triumvirate to the ominous octet: a new paradigm for the treatment of type 2 diabetes mellitus. Diabetes 2009;58(4):773-95.

14. Neuhold S, Resl M, Huelsmann M, Strunk G, Adlbrecht C, Rath C, Prager R, Luger A, Clodi M, Pacher R. Repeat measurements of glycated haemoglobin $\mathrm{A}(1 \mathrm{C})$ and N-terminal pro-B-type natriuretic peptide: 
divergent behaviour in diabetes mellitus. Eur J Clin Invest 2011;41(12):1292-8.

15. Januzzi JL, Jr., Butler J, Jarolim P, Sattar N, Vijapurkar U, Desai M, Davies MJ. Effects of Canagliflozin on Cardiovascular Biomarkers in Older Adults With Type 2 Diabetes. J Am Coll Cardiol 2017;70(6):704-712.

16. Daniels LB, Maisel AS. Natriuretic peptides. J Am Coll Cardiol 2007;50(25):2357-68.

17. Heinisch BB, Vila G, ResI M, Riedl M, Dieplinger B, Mueller T, Luger A, Pacini G, Clodi M. B-type natriuretic peptide (BNP) affects the initial response to intravenous glucose: a randomised placebocontrolled cross-over study in healthy men. Diabetologia 2012;55(5):1400-5.

18. Macia L, Tsai VW, Nguyen AD, Johnen H, Kuffner T, Shi YC, Lin S, Herzog H, Brown DA, Breit SN, Sainsbury A. Macrophage inhibitory cytokine 1 (MIC-1/GDF15) decreases food intake, body weight and improves glucose tolerance in mice on normal \& obesogenic diets. PLoS One 2012;7(4):e34868.

19. Ding Q, Mracek T, Gonzalez-Muniesa P, Kos K, Wilding J, Trayhurn P, Bing C. Identification of macrophage inhibitory cytokine- 1 in adipose tissue and its secretion as an adipokine by human adipocytes. Endocrinology 2009;150(4):1688-96.

20. Xu XY, Nie Y, Wang FF, Bai Y, Lv ZZ, Zhang YY, Li ZJ, Gao W. Growth differentiation factor (GDF)-15 blocks norepinephrine-induced myocardial hypertrophy via a novel pathway involving inhibition of epidermal growth factor receptor transactivation. J Biol Chem 2014;289(14):10084-94.

21. Bonaterra GA, Zugel S, Thogersen J, Walter SA, Haberkorn U, Strelau J, Kinscherf R. Growth differentiation factor-15 deficiency inhibits atherosclerosis progression by regulating interleukin-6dependent inflammatory response to vascular injury. J Am Heart Assoc 2012;1(6):e002550.

22. de Jager SC, Bermudez B, Bot I, Koenen RR, Bot M, Kavelaars A, de Waard V, Heijnen CJ, Muriana FJ, Weber C, van Berkel TJ, Kuiper J, Lee SJ, Abia R, Biessen EA. Growth differentiation factor 15 deficiency protects against atherosclerosis by attenuating CCR2-mediated macrophage chemotaxis. J Exp Med 2011;208(2):217-25.

23. Stahrenberg R, Edelmann F, Mende M, Kockskamper A, Dungen HD, Luers C, Binder L, HerrmannLingen C, Gelbrich G, Hasenfuss G, Pieske B, Wachter R. The novel biomarker growth differentiation factor 15 in heart failure with normal ejection fraction. Eur J Heart Fail 2010;12(12):1309-16.

24. Clodi M, Resl M, Neuhold S, Hulsmann M, Vila G, Elhenicky M, Strunk G, Abrahamian H, Prager R, Luger A, Pacher R. A comparison of NT-proBNP and albuminuria for predicting cardiac events in patients with diabetes mellitus. Eur J Prev Cardiol 2012;19(5):944-51.

25. Parving HH, Lewis JB, Ravid M, Remuzzi G, Hunsicker LG, investigators D. Prevalence and risk factors for microalbuminuria in a referred cohort of type II diabetic patients: a global perspective. Kidney Int 2006;69(11):2057-63.

26. Resl M, Vila G, Kraxner R, Pacher R, Luger A, Hulsmann M, Neuhold S, Brath H, Prager R, Clodi M. Estimated glomerular filtration rate and albuminuria: true predictors of cardiovascular events in obese patients with type 2 diabetes? Wien Klin Wochenschr 2013;125(19-20):629-33. 